\title{
The Function of the Harbormaster for the Security and Safety of Shipping
}

\author{
Abbas $^{1} \quad$ Syahruddin Nawi $^{2} \quad$ Hamzah Baharuddin $^{3} \quad$ Ilham Abbas ${ }^{3}$ \\ 1.Doctoral Student, Faculty of Law, Universitas Muslim Indonesia, Indonesia \\ 2. Professor of Law, Faculty of Law, Universitas Muslim Indonesia, Indonesia \\ 3. Associate Professor, Faculty of Law, Universitas Muslim Indonesia, Indonesia
}

\begin{abstract}
Shipping safety is very important and is the center of all aspects of the shipping world. The harbormaster as the government at the port has the responsibility to ensure the safety and security of shipping. This research is a normative-legal research using a statute, comparative and conceptual approaches. The results show that the implementation of the safety and security functions of shipping by the harbormaster is carried out in accordance with international law and national law in shipping. Optimizing the harbormaster in carrying out the safety and security functions of shipping as well as carrying out supervision of the maritime affairs of the ship will realize the achievement of safety, security and order in shipping activities.
\end{abstract}

Keywords: Harbormaster, Security and Safety of Shipping, Maritime.

DOI: $10.7176 / \mathrm{JLPG} / 105-07$

Publication date: January $31^{\text {st }} 2021$

\section{Introduction}

Indonesia has implemented Law No. 17 of 2008, Government Regulation no. 20 of 2010, Minister of Transportation Regulation No. 20 of 2015 and many other laws and regulations that regulate all matters relating to sea traffic, transportation of goods and / or people by sea, navigation and shipping activities as a means of sea transportation, including aspects of security and law enforcement. In carrying out the functions and duties of ship safety and security, the government in this case is the harbormaster given the functions and duties as regulated in Article 208 of Law No. 17 of 2008 that:

The harbormaster has the duty to carry out safety and security functions as referred to in Article 207 paragraph (1), namely: Pay attention to shipworthiness, safety, security and order at the port; Attention to orderly ship travel in port waters and shipping traffic; Paying attention to transboundary activities in port waters; Pay attention to salvage activities and underwater work; Pay attention to ship alert activities; Pay attention to scouting; Pay attention to the ups and downs of dangerous goods and hazardous and toxic waste; Pay attention to ship refueling; Pay attention to the orderliness of the embarkation and debarkation of passengers; Pay attention to island dredging and reclamation; Pay attention to the activities of building port facilities for ships; Carry out assistance to search and rescue ship accidents; Leading the pollution control and fire fighting team at the port; and Pay attention to the implementation of marine environmental protection; The inherent aspects of shipping safety include the characteristics of attitudes, values and activities related to the importance of meeting safety and security requirements related to transportation in waters and at ports. Neglecting shipping safety generally results in higher economic and environmental costs, such as reduced production, incurring medical costs, pollution and inefficient energy consumption.

Shipping is a high regulated sector where there are clear regulations regarding the role of each related party in shipping. ${ }^{1}$ The existence of marine safety regulations that prioritize third party regulations is a result of the many shipping accidents caused by human errors. At the operational level, the harbormaster, ship owner and skipper are the trident of shipping safety. The three of them have roles and responsibilities as defined in the maritime affairs of the ship, which is explicitly regulated in article 1 paragraph (33) of Law No. 17 of 2008 which explains that shipworthiness is a condition of a ship that meets the requirements of ship security, crew members, cargo, health and welfare of crew and passengers as well as legal status of ships, security management and prevention of ship pollution, management of ship security to navigate certain waters. ${ }^{2}$

Shipping is not only about sea transportation, but more generally includes existing facilities and infrastructure, as well as guarantees of safety, security and protection in Indonesia's maritime environment. ${ }^{3}$ This is what creates

\footnotetext{
${ }^{1}$ Baranyanan, A. S., Kuswara, K., \& Nasrun, N. (2020). Kajian Pemodelan Dan Implementasi Alat Keamanan Kebakaranpada Km. Satria Express 99, Askar Saputra 07 Dan Km. Queen Marydalam Menunjang Keselamatan Transportasi Laut Ternate-Halmahera Selatan. Clapeyron: Jurnal Ilmiah Teknik Sipil, 1(1). See too, Rayyan, A. (2017). Tanggungjawab Hukum Atas Terjadinya Kecelakaan Kapal Km Zahro Express Di Pulau Tidung Dihubungkan Dengan Kuhd Dan Undang-Undang Nomor 17 Tahun 2008 Tentang Pelayaran. (Fakultas Hukum Universitas Pasundan). Accessed on http://repository.unpas.ac.id/id/eprint/31391

${ }^{2}$ Ibid.

${ }^{3}$ Kimbal, M., \& Kumayas, N. (2019). Pengawasan Pemerintah Dalam Penanganan Keselamatan Berlayar (Studi Di Kantor Kesyahbandaran Dan Otoritas Pelabuhan Kelas III Kota Manado). Jurnal Eksekutif, 3(3).
} 
a variety of marine support, routine supervision and maintenance and the need for marine and ship safety guarantees as a guarantee of safety, security and protection in the maritime environment. ${ }^{1}$ Sea transportation requires many facilities, such as marine warehouses, sea guides, cargo equipment, tugs and support ships. ${ }^{2}$ In addition, the facilities that must be provided for securing port channels, ship lighting, port access points and patrol boats are also not yet available for pioneer ships to guide ships to port docks. ${ }^{3}$

The enactment of Law No. 17 of 2008 relating to shipping has undergone many improvements that will improve the function of the porters and safety and security issues on shipping are the main responsibility at the port because the main problem in shipping accidents on shipping is a matter of a person's ability and expertise in carrying out port duties.

The duties of the harbormaster in the field of shipping security and safety according to Indonesian law are as law enforcers in the field of Indonesian shipping safety and security, as head of government at ports or as coordinators of all activities in ports, as supervisors and are responsible for shipping security and safety in Indonesia, and as a shipping document issuer. The responsibility of the harbormaster in shipping security and safety according to Indonesian law is to ensure that the ship is fit for sailing and the risk of sea accidents due to ship unworthiness, overcoming marine pollution, making efforts to prevent and minimize marine pollution and participating in search and rescue of victims in the event of a ship accident when there is a disturbance in shipping. ${ }^{4}$

The importance of safety and security issues, as well as all marine transportation activities is the responsibility of the port because one of the main problems in shipping accidents during shipping is the problem of a person's ability and expertise to carry out his duties both in carrying out all duties at the port and in the performance of cooperation or relations with agencies other businesses assigned to supervise shipping and shipping itself. This study aims to analyze the implementation of the harbormaster function in the effort of shipping safety and security.

\section{Methods of Research}

This research is a normative-legal research using a statute, comparative and conceptual approaches. ${ }^{5}$ Its data will be provided from primary and secondary legal materials. The primary legal materials resulted from some relevant laws and legislation. Those legal material collected are analysed descriptively related to the problems and prescriptively.

\section{Results and Discussion}

Major works related to the law of the sea can be traced back to the 1600s. Mare Liberum by Hugo Grotius in 1609 is one of the earliest academic writings on the subject. The book applies the terms 'safety' and 'safe' several times in describing the imagined situation at sea. ${ }^{6}$ First, Grotius highlighted how the King of Spain told the Counselor and Viceroy of India to organize a fleet suitable for a particular mission in a certain part of the sea, as well as to select the appropriate command and head for it. ${ }^{7}$ In this historic article, conformity is a factor related to safety. Grotius also underlined further that maritime trade between Spain and India is very important to the safety of Spain and therefore cannot be maintained without weapons. ${ }^{8}$ The thinking of Grotius led discussions in other major works of international maritime law such as William Welwood with his work, "De Dominio Maris," in 1615 and John Selden with "Mare Clausum Seu de Dominio Maris" in 1635. Overall, this publication suggests that some of the important factors related to maritime safety in the 17th century consisted of at least two sets of factors: the technical element (ship type) and the human element (crew capacity). These works also show that maritime safety is an integral part of nations' strategic thinking, as they compete and try to win wars by ensuring the safety of sea lanes.

Maritime security is implicitly discussed in The Influence of Sea Power upon History 1660-1783, published in 1890 by Alfred Thayer Mahan. Amid an extraordinary recipe for how a country can become a leading maritime nation, the book highlights the need for maritime security to achieve that vision. ${ }^{9}$ Interestingly, Mahan distinguished the concept between controllable aspects of maritime safety (such as maritime traffic safety, port safety, safety points in all international waters to ensure shipping operations, naval efficiency, and property safety on board) and those aspects that uncontrolled (such as natural harbor and coastal landscapes, and the potential for monsoons). Mahan's work is one of the leading works of a time when a social science perspective was still

\footnotetext{
${ }^{1}$ Indah, D. J. (2019). Analisis Pentingnya Status Hukum Kapal Guna Mewujudkan Keselamatan Pelayaran Di Pelabuhan Tanjung Emas Semarang (Politeknik Ilmu Pelayaran Semarang). Accessed on http://repository.pip-semarang.ac.id/2136/

${ }^{2}$ Baranyanan, A. S., Kuswara, K., \& Nasrun, N. Op. Cit.

${ }^{3}$ Kimbal, M., \& Kumayas, N. Op. Cit.

${ }^{4}$ Ibid.

${ }^{5}$ Marzuki, P. M. (2009). Penelitian Hukum, $5^{\text {th }}$ ed. Jakarta: Kencana.p. 59

${ }^{6}$ Centre for Strategic and International Studies. (2020). Maritime Safety in Indonesia: Mapping the Challenges and Opportunities. Jakarta: Centre for Strategic and International Studies (CSIS). p. 8

${ }^{7}$ Hugo Grotius. (2004). The Free Sea, trans. Richard Hakluyt, ed. David Armitage. Indianapolis: Liberty Fund. p 62

${ }^{8}$ Ibid. p. 77

${ }^{9}$ Mahan, A.T. (2010). The Influence of Sea Power upon History 1660-1783. Cambridge: Cambridge University Press.
} 
dominant in discussions of safety at sea. The way of studying maritime safety changed with the extraordinary technological advances of the early 20th century. The sinking of the unprecedented large-scale passenger ship RMS Titanic in the North Atlantic Ocean in 1912 sparked a more scientific analysis. The main cause of the Titanic accident was the dynamics of pressure on the sea level that brought icebergs to the Titanic's shipping lanes, accompanied by the absence of regulations regarding shipbuilding technology. ${ }^{1}$

The initial international response then was the formulation of the first Convention on the Safety of Life at Sea (SOLAS) in the following two years. More than half of the provisions in SOLAS 1914 deal with technical components of shipbuilding, including but not limited to construction, radiotelegraphy, life-saving equipment and fire protection. This marked the start of a science-led paradigm on maritime safety, which was further emphasized by the establishment of the Maritime Safety Committee by the International Maritime Consultative Organization (IMCO, now called IMO) in 1959. At its first session, the committee was mandated to cover four thematic areas, Safety of Life at Sea, International Code of Signals, Measurement of Tonnage, and the Prevention of Pollution by Oil. $^{2}$

There are several important international conventions at this time, including: Safety Of Life At Sea (SOLAS 1974) which has also been ratified by Indonesia. The convention has been amended by the 1978 Protocol, in particular concerning safety requirements for tankers. Indonesia has also ratified the convention even though the legislation regarding shipping safety that is still formally valid is the Shipping Regulations and Ordinances based on the 1929 SOLAS Convention. Another important convention is the Convention on the International Regulations for Preventing Collisions at Sea, 1972 (COLREG Convention 1972), International Convention on Load Lines, 1966 (LOAD LINES Convention 1966) and International Convention on Tonnage Measurement of Ships, 1969 (TONNAGE Convention 1969) which have also been ratified by Indonesia. In the International Convention on Standards of Training, Certification and Watchkeeping for Seafarers, 1978 (STCW Convention 1978) has recently come into effect. This Convention is seen as a milestone for action to improve safety at sea and prevention of marine pollution and prevention of marine pollution through international standardization of standards and procedures for training, certification and safeguards for seafarers of all categories and levels.

The Indonesian government is currently considering ratifying the convention. This is actually something that is urgent so that Indonesian ships visiting other countries implementing the convention do not experience difficulties. Several other conventions include the International Convention for Safe Containers, 1972 (CSC Convention 1972), Convention on the International Maritime Satellite Organization, 1976 (INMARSAT Convention 1976), Torremolinos International Convention for the Safety of Fishing Vessels 1977 and International Convention Maritime Search And Rescue, 1979 With Annex And 1998 Amendments To The International Convention On Maritime Search And Rescue, 1979.

Finding an explicit definition of maritime safety from the available academic literature can be challenging. One of the difficulties is the fact that maritime safety has in many cases and research been taken to be underestimated, as something that is generally understood. Much of the literature considers the concept of maritime safety to be self-explanatory and suggests that further efforts to decipher the concept are unnecessary. Yet in providing a conceptual basis, several works are noteworthy: Spiro and Parfitt discuss the application of cost-benefit analysis to marine safety measures ${ }^{3}$ Hetherington, Flin, and Mears highlight the human element of shipping safety; ${ }^{4}$ Panayides noted the importance of maritime policy and research to the maritime industry; ${ }^{5}$ and Fenstad, Dahl, and Kongsvik closely examined how ship safety is affected by external actors - ship owners and regulatory authorities. ${ }^{6}$

All users of sea transportation in Indonesia in particular and the world in general always prioritize safety and security issues, which are then followed by aspects of affordable costs, speed and timeliness, and aspects of comfort. Preventing marine accidents such as drowning, burning, etc. is a matter related to the safety and security of marine transportation. For the implementation of the improvement of sailing safety, the Directorate General of Sea Transportation has issued policies to prevent shipping accidents, such as making shipping announcements regarding increased safety supervision of passenger ships, announcements about weather conditions in Indonesian waters, such as telegrams regarding readiness for bad weather at sea. ${ }^{7}$

Shipping which is part of sea transportation as mandated by Law No. 17 of 2008 is a very strategic part from the perspective of the Indonesian nation, as well as an important means of supporting the goals of the unity and

\footnotetext{
${ }^{1}$ Linkin, M. E. (2007). Icebergs Ahead!: How Weather Doomed The Titanic. Weatherwise, 60(5), 20-25.

${ }^{2}$ Simmonds, K. R. (1963). The Constitution of the Maritime Safety Committee of IMCO. Int'l \& Comp. LQ, 12, 56.

${ }^{3}$ Spiro, E., \& Parfitt, A. (1995). Applying cost—benefit analysis to marine safety measures. Maritime Policy and Management, 22(3), 215223.

${ }^{4}$ Hetherington, C., Flin, R., \& Mearns, K. (2006). Safety in shipping: The human element. Journal of safety research, 37(4), 401-411.

${ }^{5}$ Panayides, P. M. (2006). Maritime policy, management and research: role and potential. Maritime Policy \& Management, 33(2), 95-105.

${ }^{6}$ Fenstad, J., Dahl, Ø., \& Kongsvik, T. (2016). Shipboard safety: exploring organizational and regulatory factors. Maritime Policy \& Management, 43(5), 552-568

${ }^{7}$ Kadarisman, M. (2017). Kebijakan keselamatan dan keamanan maritim dalam menunjang sistem transportasi laut. Jurnal Manajemen Transportasi \& Logistik, 4(2), 177-192
} 
integrity of the Republic of Indonesia as a maritime country. Shipping or sea transportation, which is a part of transportation that cannot be separated from other parts of transportation means that are able to face future changes, has certain characteristics because it is able to carry out mass transportation that can connect and reach regions through waters so that it has a strong development potential and role, both nationally and internationally, as well as being able to encourage and support national development to improve people's welfare in accordance with the mandate of the Pancasila and the Constitution of $1945 .^{1}$

The shipping safety and security system is thus an important factor that must be considered and as a basis and benchmarks for decision making in determining the feasibility of a voyage, both in terms of ship facilities and infrastructure such as navigation systems and the personnel involved. involved in this. The following maritime safety and security are the main policies that must be prioritized in shipping in supporting smooth sea transportation in Indonesia as an archipelagic country. ${ }^{2}$

Control over the sea means that the government is obliged to carry out governance in the field of law enforcement at sea, both against the threat of violations, the use of waters and the maintenance and creation of optimal shipping safety. Based on Law No.17 of 1985 for Indonesia by the UN convention, it means that Indonesia has been recognized as an archipelago by the international community.

Indonesia's geographic location, which is located between the continents of Asia and Australia and between the Indian and Pacific Oceans, has placed Indonesia in a strategic position in the economic, political, socio-cultural, and defense and security sectors. In addition, the location and marine resources also make Indonesia very important for countries from various regions. However, this strategic position is not only an opportunity, but also an obstacle for the nation. Indonesia in realizing the ideals of the nation), because besides having a beneficial impact at the same time it can threaten Indonesia's interests, it creates complex problems in the fields of security, justice, economy and national defense.

Sea transportation as one of the transportation capital is regulated in one integrated national transportation unit to realize the provision of transportation services in accordance with the needs and availability of safe, comfortable, orderly and efficient transportation services. To achieve this, the government naturally has an important role to play in supporting the smooth running of shipping, namely by enforcing the law at sea.

One of the efforts in the field of legal supervision at sea is the supervision of ships sailing in Indonesian waters. Ships that meet the seaworthy requirements that can sail in the Indonesian sea. In Article 1 number 33 Law no. 17 of 2008, shipworthiness is a condition of a ship that meets the requirements of ship safety, prevention of water pollution from ships, crew members, cargo lines, cargo, crew welfare and passenger health, legal status of ships, management of security and prevention of ship pollution, and management of security. vessels for navigation in certain waters.

The importance of a sailing approval letter is specifically regulated in Law No. 17 of 2008. Although there are regulations for sailing approval letters, it is not uncommon to find various sea transportation accidents caused by negligence in issuing shipping permits. Safety and security issues as well as shipping activities are the responsibility of the port. One of the main problems in maritime shipping accidents is the problem of a person's ability and expertise in carrying out his or her fatherly duties in issuing shipping certificates, navigation permits, shipping safety and security, as well as all marine transportation activities in Indonesian waters.

The duties and powers of the harbormaster based on the Umdang Law No. 17 of 2008, namely carrying out the functions of shipping safety and security, including implementation, supervision and law enforcement in the field of transportation in waters and ports. and protection of the maritime environment in ports.

Ship safety is the condition of a ship that meets the requirements for material, construction, building, machinery and electricity, stability, construction and auxiliary equipment and radio, ship electronics, which is proven by a certificate after inspection and testing. In accordance with the provisions of laws and regulations relating to Indonesian shipping, the port skipper has the task of carrying out safety and security functions, namely:

1) Overseeing the maritime affairs of the ship, safety, security and order at the port;

2) Overseeing orderly ship traffic in waters, ports and shipping lanes;

3) Overseeing the activity of towing ships;

4) Overseeing the orderliness of the embarkation and debarkation of passengers;

5) Supervise the loading and unloading of dangerous goods and hazardous and toxic waste.

Security and safety is the most important thing in transportation, not only in the national scope, but also in the international sphere. In this effort, the government in the maritime sector continues to improve the development of marine navigation and marine transportation. The sea is not only limited to natural resources, but also as a means of communication, meaning that the use of the sea for inter-island, land and intercontinental shipping, both for passenger and goods transportation, must be guaranteed for the security and safety of local and international

\footnotetext{
${ }^{1}$ Redita, W., Prakoso, L. Y., \& Hipdizah, H. (2020). Implementasi Kebijakan Vessel Traffic Services Direktorat Jenderal Perhubungan Laut Di Selat Sunda Dalam Keselamatan Pelayaran Terhadap Strategi Pertahanan Laut. Strategi Pertahanan Laut, 6(1).

${ }^{2}$ Wulan, S. E. R. (2020). Pengawasan Hukum Syahbandar Dalam Upaya Mewujudkan Keselamatan, Keamanan Dan Ketertiban Penumpang Speed Boat Di Pelabuhan Tarakan. Journal de Facto, 7(1), 108-126
} 
shipping supported by ship security facilities. such as Shipping Navigation Assistance Facilities (SBNP), ship telecommunications, national navigation vessels which are the responsibility of local governments to implement them. In addition, shipping activities with a wide sea and coastal surface area and increasingly extreme climatic conditions also tend to cause accidents, this is a problem or challenge in the field of shipping safety. All parties involved in shipping safety must anticipate and be prepared for climate change and prepare adequate facilities and infrastructure.

Maritime safety and security, including the safety and security of transportation in waters and ports, as well as protection of the maritime environment, must be carried out carefully by the relevant agencies as stakeholders, ${ }^{1}$ in this case it is specifically regulated as the elaboration of the shipping law through the Regulation of the Minister of Manpower, Office of the Harbormaster and Port Authority.

Foreign ships that will enter Indonesian territorial waters are required to follow ship inspection procedures to continue their previous voyages. Port state control is carried out by the Harbormaster Section. The results of the above foreign vessel inspection are divided into: (a) seaworthy; (b) substandart; and (c) unsafe. ${ }^{2}$

The follow-up or decision from Seaworthy is to issue a clearance out permit (Permit to leave the port); In substandard circumstances, clarification is required with the ship operator; and unsafe conditions require corrective action and even prevent ships from going to sea. Ships that have been declared seaworthy can sail with their destination or to a special port provided by the government, namely a special port for ocean shipping. If a ship is declared unsafe or unsuitable for shipment, the ship must repair the ship's systems or equipment which have been declared damaged or not seaworthy to perform safety and security functions during the voyage.

According to Article 1 number 33 Law no. 17 of 2008, shipworthiness is a condition of a ship that meets the requirements of ship safety, prevention of water pollution from ships, crew members, cargo lines, loading, crew welfare and passenger health, legal status of ships, management of safety and prevention of pollution from ships, and management safety of ships to sail in certain waters. The feasibility of a ship in accordance with its operational area includes: ship safety, prevention of ship pollution, ship manning, ship loading and unloading routes, crew welfare and health of passengers, legal status of ships, security management and pollution prevention from ships, ship security management. The feasibility of the ship is proven by completing administrative and technical requirements.

Administrative requirements in the form of security certificates such as citizenship certificates, measurement documents, security certificates, shipyards, marine equipment security certificates, radio certificates and certificates held, as well as technical requirements such as supporting equipment for security devices at sea must first be fulfilled so that the ship has a seaworthy status. Maritimeity of ships is closely related to shipping safety. ${ }^{3}$ Marine if not assisted by marine safety equipment, the risk of shipping accidents will increase. Ships that are seaworthy are proven by having a Marine Ship Certificate. The Ship Marine Feasibility Certificate issued by the port captain is based on the results of class test data from the Indonesian Classification Bureau (BKI).

The importance of the role of the harbormaster in supervising the maritime nature of the ship is reflected in the Indonesian shipping law related to ship safety. Some things that require the attention of the harbormaster in his supervision are ship material, shipbuilding, shipyard, ship engineering and electricity, ship stability, staging and equipment including auxiliary equipment and radio, and ship electronics. Users of sea transportation services using ships that are not seaworthy can cause losses to the goods being transported so that passengers and crew lose their lives.

To prevent this, the harbormaster performs checks in the form of:

a) Annual Inspection, checked every 12 months while floating on the shipyard.

b) Major examination, which is carried out every 4 years at the same time as the annual doc.

c) Inspection or repair of damage is carried out if someone is damaged which affects the perfection of the ship.

d) Additional checks, are carried out if a waiver is required, for example the transportation of passengers, transportation of dangerous cargo and others.

Seaworthy conditions must always be maintained, among others by maintaining the in-house crew, marine engine, safety equipment and other aids so that everything is in good condition and ready to use when needed. Article 207 paragraph (2) of Law No. 17 of 2008, states that the harbormaster participates in the search or rescue of sea transportation if the sea transport experiences an accident or disruption during shipping activities. ${ }^{4}$

The role of the harbormaster in the field of supervision is very important, this can be seen in the Indonesian

\footnotetext{
${ }^{1}$ Maulita, M. (2020). Prosedur Pemeriksaan Sertifikat Bahan Kimia Berbahaya Oleh Kupp Kelas I Loktuan Guna Mendapatkan Surat Persetujuan Berlayar. Jurnal Maritim, 10(2), 25-38.

${ }^{2}$ Bayuputra, T. B. (2015). Tinjauan Yuridis Mengenai Peran Syahbandar Dalam Kegiatan Pelayaran Angkutan Laut Di Indonesia. Lex et Societatis, $3(3$.

${ }^{3}$ Aguw, R. (2013). Tanggung Jawab Syahbandar Dalam Keselamatan Pelayaran Ditinjau Dari UU Pelayaran No. 17 Tahun 2008 Tentang Pelayaran. Lex Administratum, 1(1).

${ }^{4}$ Article 1 point 56 of Law No. 17 of 2008
} 
shipping law regarding ship safety standards, there are several things that need attention from the harbormaster in his supervision, namely:

1) Ship material

2) Ship building

3) Ship machinery and electricity

4) Stability of the ship

5) Arrangement and equipment including auxiliary equipment and radio

6) Ship electronics

The harbormaster is the government at the port appointed by the Minister and has the highest authority to implement and monitor compliance with the provisions of laws and regulations to ensure the safety and security of shipping, as well as coordination of government activities at the port. To ensure the safety of shipping in supporting the smooth movement of ships at sea, competent, capable and competent crew members are required, so that every ship that will sail must be manned with sufficient and suitable crew to carry out its duties. board a ship based on its position by taking into account the size of the ship, ship arrangement and shipping area.

Article 1 point 33 of Law No. 17 of 2008 states that shipworthiness is the condition of the ship that meets the requirements of ship safety, prevention of water pollution from ships, manning, loading lines, cargo, crew welfare and passenger health, legal status of ships, safety management and prevention of pollution from ships, and management safety of ships to sail in certain waters.

Sea transportation is a mode that plays an important role in the Indonesian transportation system. ${ }^{1}$ Sea transportation plays a role as a means of realizing an understanding of the archipelago, especially in the context of advancing the unity of the national economy which is considered an inseparable part of the national transportation system. This is because sea transportation is used as a transportation service, both local (Interrinsulair) and overseas (Ocean Going). ${ }^{2}$ In addition, sea transportation is considered to have high economic value because it is more effective and efficient than transportation by air. This is because ships have a larger and cheaper transport capacity.

In order for the activities referred to above to be carried out properly, it is necessary to have a good supervisory role for passengers. This is of course a concern for the harbormaster, considering that they are the authorities at the port who must play an active role in maximizing their authority, especially in monitoring activities of passengers at the port. However, the reality found in the field is that there are still people who do not fully feel comfortable when they want to travel by boat. The reason that is often cited by passengers is because of the inaccuracy of the supervision activities carried out by the harbormaster officer.

The enactment of Law No. 17 of 2008 has undergone many improvements that have led to an increase in the portability function. The issue of safety, security and order in shipping is the main responsibility, because one of the problems with the number of victims of sea transportation users is the lack of competence and understanding of a person in carrying out his harbormaster duties. Therefore, anyone who carries out the task of patience must fully understand every task that must be carried out.

According to Law No. 17 of 2008 Article 207 paragraph (1), states that the harbormaster carries out the safety and security functions of shipping which include implementation, supervision and law enforcement in the field of transportation in waters, ports, and protection of the maritime environment at ports.

In order to support the achievement of national development goals, shipping is a very decisive element in the smooth running of sea transportation, as regulated in Law No. 17 of 2008. Incompatibility in handling sea transportation systems and problems, as well as an imbalance of attention to shipping safety issues, can hamper the provision of transportation services throughout Indonesia.

\section{Conclusion}

The implementation of the safety and security function of shipping by the harbormaster is carried out in accordance with international law and national law in shipping. Optimizing the harbormaster in carrying out the safety and security functions of shipping as well as carrying out supervision of the ship's maritime affairs will realize the achievement of safety, security and order in shipping activities.

\section{References}

Aguw, R. (2013). Tanggung Jawab Syahbandar Dalam Keselamatan Pelayaran Ditinjau Dari UU Pelayaran No. 17 Tahun 2008 Tentang Pelayaran. Lex Administratum, 1(1).

Bakhtiar, H. S., Dhanur, N. A., Ashri, M., \& Hendrapati, M. (2016). Air Defence Identification Zone (ADIZ) in International Law Perspective. JL Pol'y \& Globalization, 56, 16.

\footnotetext{
${ }^{1}$ Kadarisman, M., Yuliantini, Y., \& Majid, S. A. (2016). Formulasi kebijakan sistem transportasi laut. Jurnal Manajemen Transportasi \& Logistik, 3(2), 161-183. See too, Putra, A. A., \& Djalante, S. (2016). Pengembangan Infrastruktur Pelabuhan Dalam Mendukung Pembangunan Berkelanjutan. Jurnal Ilmiah Media Engineering, 6(1).

${ }^{2}$ Wulan, S. E. R. Op. Cit.
} 
Bakhtiar, H. S., Noor, S. M., \& Magassing, A. M. (2017). Violation of the sovereignty of indonesia airspace by foreign aircraft. International Journal of Advanced Research (IJAR), Februari, 2107-2113.

Baranyanan, A. S., Kuswara, K., \& Nasrun, N. (2020). Kajian Pemodelan Dan Implementasi Alat Keamanan Kebakaranpada Km. Satria Express 99, Askar Saputra 07 Dan Km. Queen Marydalam Menunjang Keselamatan Transportasi Laut Ternate-Halmahera Selatan. Clapeyron: Jurnal Ilmiah Teknik Sipil, 1(1).

Bayuputra, T. B. (2015). Tinjauan Yuridis Mengenai Peran Syahbandar Dalam Kegiatan Pelayaran Angkutan Laut Di Indonesia. Lex et Societatis, 3(3).

Centre for Strategic and International Studies. (2020). Maritime Safety in Indonesia: Mapping the Challenges and Opportunities. Jakarta: Centre for Strategic and International Studies (CSIS).

Fenstad, J., Dahl, Ø., \& Kongsvik, T. (2016). Shipboard safety: exploring organizational and regulatory factors. Maritime Policy \& Management, 43(5), 552-568.

Hendrapati, M., Sumardi, J., \& Bakhtiar, H.S. (2017). Offshore Installation Removal in the Interest of Navigation Safety from International Law Point of View. JL Pol'y \& Globalization, 66, 194.

Hetherington, C., Flin, R., \& Mearns, K. (2006). Safety in shipping: The human element. Journal of safety research, 37(4), 401-411

Hugo Grotius. (2004). The Free Sea, trans. Richard Hakluyt, ed. David Armitage. Indianapolis: Liberty Fund.

Indah, D. J. (2019). Analisis Pentingnya Status Hukum Kapal Guna Mewujudkan Keselamatan Pelayaran Di Pelabuhan Tanjung Emas Semarang(Politeknik Ilmu Pelayaran Semarang). Accessed on http://repository.pip-semarang.ac.id/2136/

Kadarisman, M., Yuliantini, Y., \& Majid, S. A. (2016). Formulasi kebijakan sistem transportasi laut. Jurnal Manajemen Transportasi \& Logistik, 3(2), 161-183

Kadarisman, M. (2017). Kebijakan keselamatan dan keamanan maritim dalam menunjang sistem transportasi laut. Jurnal Manajemen Transportasi \& Logistik, 4(2), 177-192

Kimbal, M., \& Kumayas, N. (2019). Pengawasan Pemerintah Dalam Penanganan Keselamatan Berlayar (Studi Di Kantor Kesyahbandaran Dan Otoritas Pelabuhan Kelas III Kota Manado). Jurnal Eksekutif, 3(3).

Linkin, M. E. (2007). Icebergs Ahead!: How Weather Doomed The Titanic. Weatherwise, 60(5), 20-25.

Marzuki, P. M. (2009). Penelitian Hukum, $5^{\text {th }}$ ed. Jakarta: Kencana.

Mahan, A.T. (2010). The Influence of Sea Power upon History 1660-1783. Cambridge: Cambridge University Press.

Maulita, M. (2020). Prosedur Pemeriksaan Sertifikat Bahan Kimia Berbahaya Oleh Kupp Kelas I Loktuan Guna Mendapatkan Surat Persetujuan Berlayar. Jurnal Maritim, 10(2), 25-38.

Panayides, P. M. (2006). Maritime policy, management and research: role and potential. Maritime Policy \& Management, 33(2), 95-105.

Putra, A. A., \& Djalante, S. (2016). Pengembangan Infrastruktur Pelabuhan Dalam Mendukung Pembangunan Berkelanjutan. Jurnal Ilmiah Media Engineering, 6(1).

Rayyan, A. (2017). Tanggungjawab Hukum Atas Terjadinya Kecelakaan Kapal Km Zahro Express Di Pulau Tidung Dihubungkan Dengan Kuhd Dan Undang-Undang Nomor 17 Tahun 2008 Tentang Pelayaran. (Fakultas Hukum Universitas Pasundan). Accessed http://repository.unpas.ac.id/id/eprint/31391

Redita, W., Prakoso, L. Y., \& Hipdizah, H. (2020). Implementasi Kebijakan Vessel Traffic Services Direktorat Jenderal Perhubungan Laut Di Selat Sunda Dalam Keselamatan Pelayaran Terhadap Strategi Pertahanan Laut. Strategi Pertahanan Laut, 6(1).

Simmonds, K. R. (1963). The Constitution of the Maritime Safety Committee of IMCO. Int'l \& Comp. LQ, 12, 56. Spiro, E., \& Parfitt, A. (1995). Applying cost—benefit analysis to marine safety measures. Maritime Policy and Management, 22(3), 215-223.

Wulan, S. E. R. (2020). Pengawasan Hukum Syahbandar Dalam Upaya Mewujudkan Keselamatan, Keamanan Dan Ketertiban Penumpang Speed Boat Di Pelabuhan Tarakan. Journal de Facto, 7(1), 108-126 